\title{
THE EFFORTS OF KLATEN REGENCY GOVERNMENT IN ENHANCING COMMUNITY WELFARE THROUGH PEOPLE-BASED ECONOMY PROGRAM REALIZATION
}

\author{
Wasana Muhammad Titis*, Samudro Bhimo Rizky, Soesilo Albertus Maqnus \\ Faculty of Economy and Business, University of Sebelas Maret, Indonesia \\ *E-mail: mtitismn@gmail.com
}

\begin{abstract}
The aims of the present research are: to comprehend the efforts of Klaten Regency government in enhancing community's welfare through realizing people-based economy program; to know what factors that influence the efforts of Klaten Regency government in enhancing community's welfare through realizing people-based economy program. This study uses qualitative research method focusing on the realization of People-based Economy in improving community's welfare comprising of Rice for Poor (Raskin), Poor Students Assistance (Bantuan Siswa Miskin/BSM), and Household-targeted Social Assistance (Program Keluarga Harapan/PKH). The findings found that the efforts of Klaten Regency government in enhancing community's welfare through realizing people-based economy program are by planning Social Protection Extension and Acceleration Program (also known as Program Percepatan dan Perluasan Perlindungan Sosial/P4S) as compensation of fuel price increase. The program is the social security net consisting of ricesubsidized program extension for low-income community (Subsidy in form of Rice for Poor), Household-targeted Social Assistance (Program Keluarga Harapan/PKH), and Poor Students Assistance (Bantuan Siswa Miskin/BSM). The factors that influence the efforts of Klaten Regency government in enhancing community's welfare through realizing peoplebased economy program are such as: Communication, Resources, Disposition or Attitude, and Bureaucracy Structure. As a conclusion, it can be stated that the programs have been running well but the problems are also along with its realization so that its realization system still needs to be improved.
\end{abstract}

\section{KEY WORDS}

Community, Klaten, people-based economy program, welfare.

Poverty until nowadays is still the biggest concerned problem of Indonesian that has not been solved completely yet. Hence, Poverty Reduction Program, both in Indonesia generally and in Central Java specifically, is indeed one of the urgent programs to implement. Poverty is a problem of development marked by unemployment, backwardness, and adversity. The case of unemployment also attracts attention in order to develop economy that requires equity. World Bank and UNDP (United Nations Development Programme) apply definition of poverty that covers aspects like basic needs, lifestyle determined by person, choice, asset, capability, social inclusion, inequality, human rights, settlement, vulnerability, empowerment, and subjective welfare (Locatelli, 2009; World Bank, 2008). World Bank has defined poverty in global parameter which is poverty is a matter of lackness with income minimum US\$ 1 per day (Albornoz, 2007).

Based on the data from Central Bureau of Statistics (BPS, 2015), the total of poor community in Central Java Province is 4.505 .780 people (the second highest in Java island) or $14,44 \%$ from the total of Central Java community. Many poverty reduction programs have been implemented by both Central Government and Central Java Province Government. In 2015, the government implemented Social Protection Extension and Acceleration Program (P4S) in the effort of decreasing poverty problems that arise because of fuel subsidy reduction.

P4S Program implemented in Central Java Province especially Klaten Regency consists of Rice for Poor (Raskin), Poor Students Assistance (Bantuan Siswa Miskin/BSM) and Household-targeted Social Assistance (Program Keluarga Harapan/PKH). The aims of 
conducting Rice for Poor program is to reduce Targeted Household (RTS) expense through fulfilling half of basic needs in form of rice. Poor Students Assistance (BSM) is a help of government in form of personal assistance given directly for students from all education levels (Elementary School/Islamic Elementary School, Junior High School/Islamic Junior High School, Senior High School/Vocational High School/Islamic Senior High School) coming from poor family based on the determined criteria. Household-targeted Social Assistance $(P K H)$ is a cash-giving program for a very poor household based on requirements and provisions that have been determined.

Rice for Poor and Poor Students Assistance programs have aims to fulfill poor families' needs directly, which are through staple food and education fee. While, Household-targeted Social Assistance program (PKH) focuses more on specific and targeted productive elements in which one of them can be done through Productive Economy Business (Usaha Ekonomi Produktif/UEP) by Joint Business Group (Kelompok Usaha Bersama/KUBE). The existence of Joint Business Group (KUBE-PKH) for a Very Poor Household (Rumah Tangga Sangat Miskin/RTSM) in community is a form of people-based economy program realization. This program will be the place to improve productive economy business especially in enhancing community welfare. Todaro (2005) expressed that there is a close relation between unemployment, income inequality, and poverty. Generally, those who do not get regular job are included to poor community group.

Even if some poverty reduction programs have been conducted, but the fact keeps showing that the total of poor society does not reduce significantly. Poverty rate in Klaten from 2011 to 2014 decreased in which it can be seen that the poverty rate in 2011 was $17,95 \%$, and in 2012 it was $16,7 \%$, in 2013 it became 15,6\%, and in 2014 it decreased to be $14,58 \%$. The highest total of poor people is in Bayat District as much 21.893 people, followed by Trucuk District as much 17.449 people.

Based on the aforementioned explanation, so evaluation is highly needed to know how far the effect of economy program realization in enhancing community's welfare. Besides, the result of the evaluation also can be used to make a decision whether the economy program realization can be continued or needs to arrange other programs for the sake of achieving society welfare of Klaten Regency.

The research questions in this study are: 1) how are the efforts of Klaten Regency government in enhancing community welfare through people-based economy program realization?; 2) what factors that influence the efforts of Klaten Regency government in enhancing community welfare through people-based economy program realization?

The objectives of this present research are: 1) to know the efforts of Klaten Regency government in enhancing community welfare through people-based economy program realization; 2) to know what factors that influence the efforts of Klaten Regency government in enhancing community welfare through people-based economy program realization.

\section{METHODS OF RESEARCH}

The present study focuses on the realization of People-Based Economy program in enhancing community's welfare in Klaten Regency, Central Java which is P4S program comprising of Rice for Poor (Raskin), Poor Students Assistance (BSM) and Householdtargeted Assistance Program $(P K H)$. The present research uses qualitative research method. According to Sugiono (1995: 4), qualitative research method is a research method used to analyze the experienced object condition in which the researcher is a key instrument. Hence, in analysis, it also needs a method that is different from qualitative research itself.

Regarding with this, the researcher utilizes interactive analysis model designed by Miles \& Huberman (1998: 45). In the analysis method, data consist of three componenets: data reduction, data presentation, and decision making and its verification (Sutopo, 2002: 91). Those three components' activities are in form of interactions with its data collection method uses cycle process. The three components are included in the analysis process, related each other as well as determining final analysis. The figure of the analysis is presented as following: 


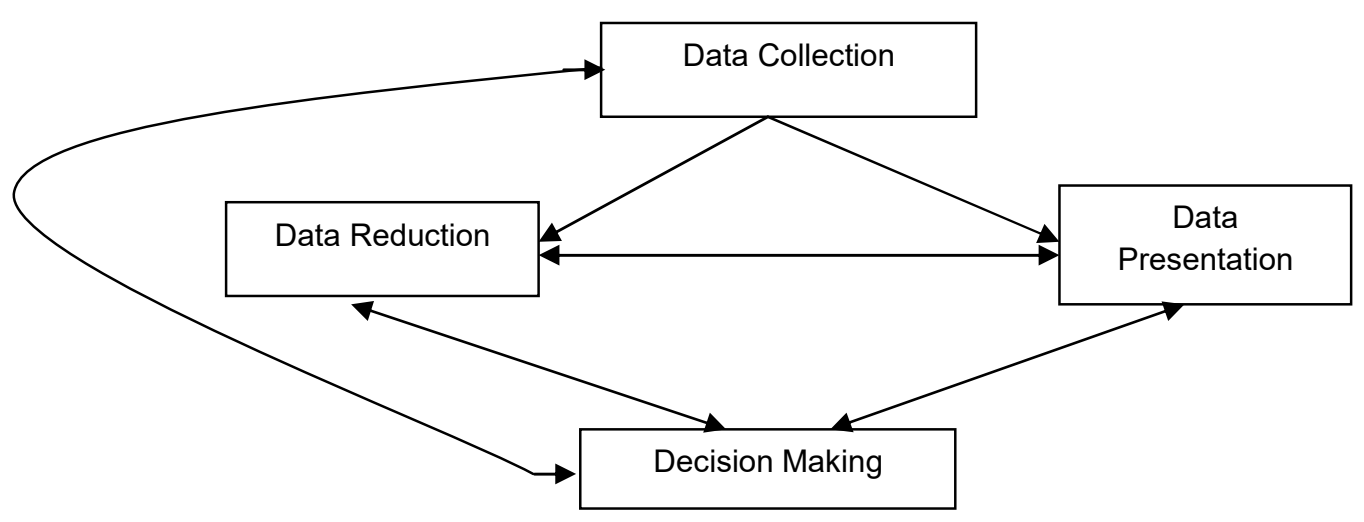

Figure 1 - Interactive Analysis Method

\section{RESULTS AND DISCUSSION}

The Efforts of Klaten Regency Government in Enhancing Community's Welfare through People-based Economy Program Realization. Based on the survey that has been done in the present study, the result regarding to informants' assessment towards indicators of peoplebased economy program realization in Klaten Regency is presented on the table as following:

Table 1 - Informants' Assessment towards Indicators of People-based Economy Program Realization in Klaten Regency

\begin{tabular}{|c|c|c|c|c|c|c|c|c|c|c|c|c|c|}
\hline \multirow{2}{*}{ No } & \multirow{2}{*}{ Indicator } & \multicolumn{5}{|c|}{ Reality } & \multirow{2}{*}{ Average } & \multicolumn{5}{|c|}{ Expectation } & \multirow{2}{*}{ Average } \\
\hline & & 5 & 4 & 3 & 2 & 1 & & 5 & 4 & 3 & 2 & 1 & \\
\hline 1 & $\begin{array}{l}\text { Rice for Poor } \\
\text { - Punctuality } \\
\text { - Efficiency and Effectivity } \\
\text { - Reliability }\end{array}$ & $\begin{array}{l}10 \\
15 \\
15\end{array}$ & $\begin{array}{l}40 \\
20 \\
12\end{array}$ & $\begin{array}{c}6 \\
15 \\
6\end{array}$ & $\begin{array}{l}2 \\
4 \\
0\end{array}$ & $\begin{array}{l}0 \\
0 \\
0\end{array}$ & $\begin{array}{l}3,86 \\
3,86 \\
2,22\end{array}$ & $\begin{array}{l}50 \\
55 \\
55\end{array}$ & $\begin{array}{c}12 \\
12 \\
8\end{array}$ & $\begin{array}{l}3 \\
0 \\
3\end{array}$ & $\begin{array}{l}0 \\
0 \\
0\end{array}$ & $\begin{array}{l}0 \\
0 \\
1\end{array}$ & $\begin{array}{l}4,33 \\
4,46 \\
4,46\end{array}$ \\
\hline 2 & $\begin{array}{l}\text { Poor Students Assistance (BSM) } \\
\text { - Punctuality } \\
\text { - Efficiency and Effectivity } \\
\text { - Reliability }\end{array}$ & $\begin{array}{c}20 \\
15 \\
5 \\
\end{array}$ & $\begin{array}{l}32 \\
32 \\
40\end{array}$ & $\begin{array}{l}6 \\
6 \\
6\end{array}$ & $\begin{array}{l}2 \\
4 \\
4\end{array}$ & $\begin{array}{l}0 \\
0 \\
0\end{array}$ & $\begin{array}{l}4,0 \\
3,8 \\
3,6\end{array}$ & $\begin{array}{l}40 \\
55 \\
70\end{array}$ & $\begin{array}{c}20 \\
16 \\
4\end{array}$ & $\begin{array}{l}3 \\
0 \\
0\end{array}$ & $\begin{array}{l}0 \\
0 \\
1\end{array}$ & $\begin{array}{l}1 \\
0 \\
0\end{array}$ & $\begin{array}{c}4,26 \\
4,73 \\
5,0\end{array}$ \\
\hline 3 & $\begin{array}{l}\text { Household-targeted Social Assistance } \\
\text { (PKH) } \\
\text { - Punctuality } \\
\text { - Efficiency and Effectivity } \\
\text { - Reliability }\end{array}$ & $\begin{array}{c}10 \\
5 \\
10\end{array}$ & $\begin{array}{l}40 \\
40 \\
44\end{array}$ & $\begin{array}{l}9 \\
6 \\
0\end{array}$ & $\begin{array}{l}0 \\
4 \\
4\end{array}$ & $\begin{array}{l}1 \\
1 \\
0\end{array}$ & $\begin{array}{l}3,93 \\
3,66 \\
3,86\end{array}$ & $\begin{array}{l}60 \\
55 \\
65\end{array}$ & $\begin{array}{c}12 \\
16 \\
8\end{array}$ & $\begin{array}{l}0 \\
0 \\
0\end{array}$ & $\begin{array}{l}0 \\
0 \\
0\end{array}$ & $\begin{array}{l}0 \\
0 \\
0\end{array}$ & $\begin{array}{c}4,8 \\
4,73 \\
4,86\end{array}$ \\
\hline \multicolumn{2}{|r|}{ Total of Informants: 15 people } & \multicolumn{5}{|c|}{ Average Total } & $\begin{array}{l}32,7 \\
3,64\end{array}$ & \multicolumn{5}{|c|}{ Average Total } & $\begin{array}{l}41,6 \\
4,62\end{array}$ \\
\hline
\end{tabular}

Source: Processed Survey Data, 2016.

Based on Table 1 above, it can be known that the realization of people-based economy program expected by informants is as much 4,62 and the value in field which is in line with reality is still under average value expected by informants which is as much 3,64.

Rice for Poor (Raskin). The government plans Social Protection Extension and Acceleration Program (P4S) as the compensation of fuel price increase. To run this, Poverty Reduction Acceleration National Team (TNP2K) established in the beginning of 2010 through President Regulation Number 15 has responsibilities to respond the slow decrease situation of poverty level and the increase of discrepancy. The President Regulation is accompanied by the issue of Minister Regulation (Permen) no. 42 of 2010 regarding Organization Structure and Work Mechanism of Program Reduction Coordination Team is a social security net consisting of rice subsidy program extension for low-income community (Subsidy of Rice for 
Poor), Household-targeted Social Assistance Program (PKH), and Poor Students Assistance Program (BSM).

It can be seen from the fact of Social Protection Card holder in the field. Social Protection Card holder in Klaten Regency is based on 14 criterias of poor household determined by Central Bureau Statistics (BPS) as the recipient of Temporary Direct Assistance for Community (BLSM), which are as follows:

1. The width of house building is less than $8 \mathrm{~m}^{2}$ per person;

2. The floor type of house building is made from soil or bamboo or cheap wood;

3. The wall type of house building is bamboo or sago palm or low-quality wood and unplastered wall;

4. No toilet facility or having a toilet together with other households;

5. Lighting source of household does not use electricity;

6. Drinking water source is from a well or unprotected water springs or river or raindrop;

7. Fuel for daily cooking is firewood or charcoal or petroleum;

8. Only consuming meat or milk or chicken once a week;

9. Only buying a set of new clothes in a year;

10. Only being able to eat once or twice a day;

11. Not being able to pay medicine costs in Health Center or Polyclinic;

12. The income source of household head like farmers with land width $500 \mathrm{~m}^{2}$, farm workers, fishermen, construction workers, plantation workers and or other jobs with income under Rp.600.000 per month;

13. The highest education of household head is uneducated or not graduated from elementary school or only graduated from elementary school;

14. Having no saving asset or a property that can be sold easily with minimum price Rp.500.000 like credit/non-credit motorcycle, gold, livestock, motor boats, or other capital goods. following:

Furthermore, its realization mechanism will be explained in some steps which are as

1. Receiving Process of Social Protection Card (KPS) for Targeted Household (RTS) distributed by PT.POS;

2. Submitting Process of Social Protection Card (KPS) \& Identity Card of Targeted Household addressed to PT.POS;

3. Verification of Social Protection Card (KPS) payment data and Identity Card of Targeted House is by officers of PT.POS;

4. Benefit Obtaining of Social Protection Extension and Acceleration Program for Targeted Household (RTS);

5. Complaint Service.

Punctuality of Realizing Rice for Poor Program (Raskin). There are three indicators reviewed in this present research which are: always be punctual to distribute rice for poor, sometimes be punctual to distribute rice for poor, and not be punctual to distribute rice for poor. Based on the survey result, $53,3 \%$ informants state that rice for poor distribution is always punctual, $33,3 \%$ informants argue that rice for poor distribution is sometimes punctual, and $13,4 \%$ informants assume that distribution of rice for poor is not punctual. The assessments are presented on the following table.

Table 2 - Informants' Assessments on Punctuality of Rice for Poor (Raskin) Program

\begin{tabular}{|c|l|c|c|}
\hline No & Description & Total & $\%$ \\
\hline 1 & Always being punctual in distributing Rice for Poor program & 8 & 53,3 \\
\hline 2 & Sometimes being punctual in distributing Rice for Poor program & 5 & 33,3 \\
\hline 3 & Not being punctual in distributing Rice for Poor program & 2 & 13,4 \\
\hline Grand Total & 15 & $100 \%$ \\
\hline
\end{tabular}

Source: Processed Survey Data, 2016.

Based on the above table, it can be known that the realization of Rice for Poor (Raskin) distribution has been running well in Klaten Regency. Moreover, based on the observation in 
the field, the unpunctuality in realizing Rice for Poor (Raskin) in Klaten Regency is caused by delays and inadequate facilities. Based on the data from Central Bureau of Statistics (BPS, September 2013), the total of poor people in Central Java Province is as much 4.704.870 people or $14,44 \%$ from the total of Central Java people. The aims of conducting Rice for Poor program (Raskin) is to reduce Targeted Household (RTS) expense through fulfilling half of basic needs in form of rice.

Efficiency and Effectivity of Rice for Poor (Raskin) Program. Efficiency means the use of community fund can gain maximum output, while effectivity means the fund must be able to achieve target or public interest goal. Efficiency here is equalized to the definition of economical shopping which is savings on budget use; while shopping effectivity is considered as output use of the activity. Based on the survey result, there are $60 \%$ informants assessing that this Rice for Poor (Raskin) program has been conducted efficiently and $40 \%$ informants also state that the realization of this program is effective.

Table 3 - Informants' Assessments on Efficiency and Effectivity of Rice for Poor (Raskin) Program

\begin{tabular}{|c|c|c|c|}
\hline No & Description & Total & $\%$ \\
\hline 1 & It is effective & 9 & 60 \\
\hline 2 & It is efficient & 6 & 40 \\
\hline \multicolumn{2}{|c|}{ Grand Total } & 15 & $100 \%$ \\
\hline
\end{tabular}

Source: Processed Survey Data, 2016.

Based on the condition and the growth of Klaten Regency's economy in the years ahead, it will still be influenced by global economy that becomes the main challenge. In enhancing community's welfare especially in Klaten Regency, the economy of Klaten Regency in years ahead is directed to be an independent region economy supported by creative economy growth. In other words, it can be stated that region economy is expected to be made with the foundation and the structure of strong economy so that the community's welfare will be achieved easily.

Therefore, the improvement and the development of region economy will be concerned and be emphasized on (1) strengthening region's economy structure by balancing the development of primary, secondary, and tertiary sectors through integrated agriculture sector enhancement done by developing agroindustry and agribusiness based on agrominapolitan in order that productivity, added value, and competitiveness are more interested by local economic agents, (2) developing region-potency-based and market-oriented business in accordance with Micro, Small, and Medium Enterprises (UMKM), (3) growing and developing the competence of UMKM to be a strong and an independent enterprise by strengthening capital and market access through cooperatives movement and existing cooperatives type development such as: Saving and Loan Cooperative and Sharia Finance Service Unit, (4) empowering the roles of UMKM in region development, job vacancies, income equity, economy growth, and community poverty reduction, (5) motivating the speed of region economy growth based on investment increase and condusive business nuance making, and (6) increasing productive resource accesses.

Reliability of Rice for Poor (Raskin) Program. Based on the analysis in the field, it is noted that the total of poor people in Klaten Regency from 2011 to 2015 tends to decrease although it is relatively slow. The total of poor community in 2011 is as much 203.052 people $(16,21 \%)$, while in 2015 it decreases to be 175.480 people $(13,47 \%)$. The poverty condition in Klaten Regency is still above average of Central Java Province. In addition, its portrayal can be seen on the Figure 2 below.

Based on the survey result, 53,3\% informants assess that this Rice for Poor (Raskin) program is reliable even if $46,7 \%$ informants believe this program is not reliable yet.

The success parameter of this Rice for Poor (Raskin) program is improving community's welfare. The government of Klaten Regency through Head of Economy Division in Region Secretariat issued Circular Letter regarding Schedule of the $13^{\text {th }}$ Rice for Poor (Raskin) Allocation Realization in 2015. The letter is addressed to all local District Head in date of 28 September 2015 Number 511/523/02 made based on Letter of Central Java 
Governor No. 740/ND.Sek./Ek/2015 date 25 September 2015 regarding to Ceiling Addition of the $13^{\text {th }}$ and the $14^{\text {th }}$ Rice for Poor in 2015. In the letter received by Public Relation Office of Region Secretariat in 1 October 2015, Klaten Regency obtained addition of Rice for Poor allocation for two months (the $13^{\text {th }}$ and the $14^{\text {th }}$ Rice for Poor (Raskin)) each 108.527 for Targeted Household (RTS) and Benefit Recipients (PM) with rice quantum as much $3.255 .810 \mathrm{kgs}$. Thus, each Targeted Household (RTS) in this policy will obtain extra rice as much $30 \mathrm{kgs}$ for two months as in line with the provision applies.

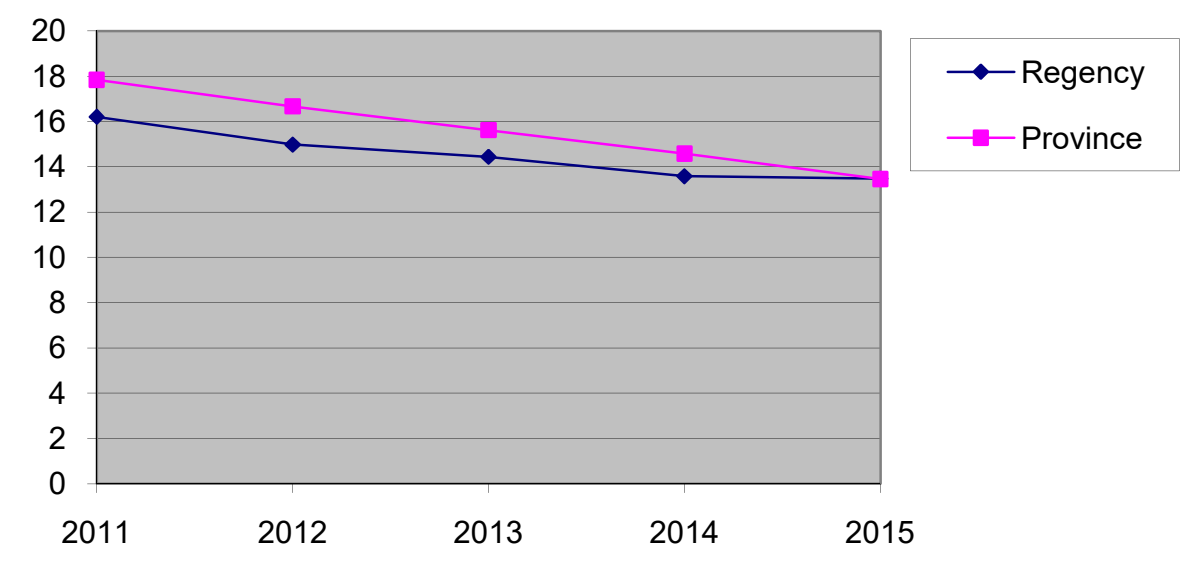

Figure 2 - Poverty Growth of Klaten toward Province in 2011-2015

Table 4 - Informants' Assessment on Reliability Rice for Poor (Raskin) Program

\begin{tabular}{|c|l|c|c|}
\hline No & \multicolumn{1}{|c|}{ Description } & Amount & $\%$ \\
\hline 1 & Reliable & 8 & 53,3 \\
\hline 2 & Not reliable & 7 & 46,7 \\
\hline \multicolumn{2}{|c|}{ Total } & 15 & 100 \\
\hline
\end{tabular}

Source: Processed Survey Data, 2016.

Poor Students Assistance Program (BSM). Poor Students Assistance Program (BSM) is a help of government in form of personal assistance given directly for students from all education levels (Elementary School/Islamic Elementary School, Junior High School/Islamic Junior High School, Senior High School/Vocational High School/Islamic Senior High School) coming from poor family based on the determined criteria. The aims of conducting this program is to eliminate the retardation for students to get education service access; to prevent dropout rate \& to attract poor students to attend school again; to assist poor students in fulfilling their personal needs in education activities and to support nine-year compulsory education and universal high school. While, the objective of realizing this program is that the poor children still can access education services especially in nine-year compulsory education and universal high school.

Punctuality of Poor Students Assistance (BSM) Program Realization. Based on survey, $53,3 \%$ informants state that the realization of BSM program is punctual, $26,7 \%$ informants mention that BSM distribution is sometimes punctual, and $20 \%$ informants believe that BSM distribution is not punctual yet.

Table 5 - Informants' Assessment on Punctuality of BSM Program Realization

\begin{tabular}{|c|l|c|c|}
\hline No & \multicolumn{1}{|c|}{ Description } & Total & $\%$ \\
\hline 1 & BSM Realization is punctual & 8 & 53,3 \\
\hline 2 & BSM Realization is sometimes punctual & 4 & 26,7 \\
\hline 3 & BSM Realization is not punctual & 3 & 20 \\
\hline Grand Total & 15 & $100 \%$ \\
\hline
\end{tabular}

Source: Processed Survey Data, 2016. 
Based on observation result in the field, BSM Program is a national program aiming to eliminate the problems of poor students to participate in attending schools by helping them to get proper education service access, to prevent dropout rate, to attract poor student to attend school again, to assist students fulfilling their basic needs in learning process, to support nine-year compulsory education (even until tertiary education), and to help school program run.

By this BSM Program, it is expected that school-aged children coming from poor households or poor familiies still attend schools and it is expected in future that the students can solve poverty which is suffered by their parents until nowadays. BSM Program also supports government's commitment to increase rate of education participation in remote and poor Regency/City.

BSM Funding is granted to students started from elementary school to Tertiary Education with details as follows:

1. BSM for Elementary School \& Islamic Elementary School is as much Rp 225.000 per semester or Rp 450.000 per year;

2. BSM for Junior High School/Islamic Junior High School is as much Rp 375.000 per semester or Rp 750.000 per year;

3. BSM for Senior High School/Vocational High School/Islamic Senior High School is as much Rp 500.000 per semester or Rp 1.000 .000 per year.

The targets of BSM Recipients are poor students which are the students of Elementary School, Junior High School, Senior High School, and Vocational High School whose parents are not able to pay their children's education free, poor parents or poor household in line with criteria as follows:

The criteria of BSM Recipients are as follows:

1. Students' Parents of Social Protection Card (KPS) holder;

2. Students of Recipient Candidate Card of Poor Students Assistance program;

3. Students' parents of Household-Targeted Social Assistance (PKH) Participant;

4. Students who are in danger of dropping out due to cost difficulties;

5. Orphans students;

6. Students who are from orphanage;

7. Students who are from the victims of accidents, disasters, work termination from a Very Poor Household and students from agricultural expertise (Vocational High School).

Efficiency and Effectivity of BSM Program Realization. Based on the survey result, $80 \%$ informants assess that BSM Program is extremely effective and efficient in helping community's welfare and $20 \%$ informants believe BSM Program is less effective and efficient.

Table 6 - Informants' Assessment on Efficiency and Effectivity BSM Program

\begin{tabular}{|c|l|c|c|}
\hline No & \multicolumn{1}{|c|}{ Description } & Amount & $\%$ \\
\hline 1 & It is efficient & 12 & 80 \\
\hline 2 & It is effective & 3 & 20 \\
\hline \multicolumn{2}{|c|}{ Total } & 15 & $100 \%$ \\
\hline
\end{tabular}

Source: Processed Survey Data, 2016.

Based on survey, $66,6 \%$ informants state that BSM Program realization is reliable to help community's welfare and $33,4 \%$ informants believe that BSM Program is not reliable yet in supporting community's welfare in Klaten Regency.

Table 7 - Informants' Assessment on Reliability BSM Program

\begin{tabular}{|c|l|c|c|}
\hline No & \multicolumn{1}{|c|}{ Description } & Amount & $\%$ \\
\hline 1 & It is reliable & 10 & 66,6 \\
\hline 2 & It is not reliable & 5 & 33,4 \\
\hline \multicolumn{2}{|c|}{ Total } & 15 & $100 \%$ \\
\hline
\end{tabular}

Source: Processed Survey Data, 2016. 
Referring to the observation result in the field, the aspect of responsibility is often related to the reliable budget management of regional government. In cases that are frequently found in the field on other government programs like program of Central Java government through Social Department, it can be stated that the government has been running poverty reduction in Central Java Province conducted by fund allocation from both Regional Government Budget (APBD) and Central Government Budget (APBN). For 2014, the poverty reduction programs conducted by Social Department of Central Java Province are:

1. Poor people handling program through Social Empowerment of Indigenous Communities Program (PS-KAT) as much 200 Families (20 Joint Business Groups/KUBE) spread in 5 Regencies covering Grobogan Regency, Blora Regency, Sragen Regency, Kendal Regency, and Wonosobo Regency with budget as much Rp. 400.000.000,- (four hundred millions rupiah).

2. Poverty Reduction of Village with total Rp. 3.377.000.000,- (Three Billions three hundreds seventy seven millions rupiah) with targets 1.200 people gathered in 120 Joint Business Groups/KUBE that will get assistance facilities @ Rp. 20.000.000,(Twenty thousand millions rupiah) with activity sites in Temanggung, Purworejo, Blora, and Jepara Regencies.

3. Poverty Reduction of Urban with total Rp. 2.350.520.000,- (Two billions three hundreds five thousand millions five hundreds twenty thousands rupiah) with targets 800 people gathered in 80 Joint Business Groups/KUBE that will get assistance facilities@ @p. 20.000.000,- (Twenty thousand millions rupiah) with activity sites in in Demak, Pati, and Pekalongan.

4. Even if some poverty reduction programs have been conducted, but the fact shows that the total of poor people do not decrease significantly. According to research done by Development and Research Board of Central Java Province, the problems faced in realizing poverty reduction can be classified into policy scale, concept, implementation, and participation.

5. From policy perspective, many policies issued by ministries and departments aiming to reduce poverty are not in line. On the perspectives of concept and implementation, poverty reduction programs are frequently not effective and there is no evaluation towards the success of the program.

6. The increase of budget and poverty activities is not in line with the decrease of poverty itself. On one side, budget politics both in center and in region do not support poverty reduction yet simply because there is a problem in determining the target of poverty reduction.

7. On the other hand, there are some problems that arise from poor people themselves, regarding to mindset, attitude, and culture that do not support changes. Mental attitude that does not expect changes becomes the main challenge.

8. The development of mindset and mental attitude are one of the most important ways to strive for poverty reduction. Therefore, in the policy concept of poverty reduction, empowerment needs to be the main approach by prioritizing independence concept. Poverty reduction should not prioritize direct assistance like Rice for Poor (Raskin) and Temporary Direct Assistance for Community (BLSM), but it should prioritize effective and specific productive elements in which it can be done through Productive Economy Enterprises (UEP) by Joint Business Group (KUBE).

Household-targeted Social Assistance (Program Keluarga Harapan/PKH). Based on the result of survey, it is found that there are $80 \%$ informants stating that the realization of $\mathrm{PKH}$ program is punctual and there are $20 \%$ informants assessing that the realization of $\mathrm{PKH}$ Program is not punctual yet.

Based on the research conducted in field, it is found that the recipients of $\mathrm{PKH}$ Program are required to sign an agreement in which its content is that the Selected Recipients Candidate must sign an agreement that in the period of getting assistance, they will: (1) Send children aged 7-15 years old and children aged 16-18 years old to attend school but they do not finisih nine-year compulsory education yet; (2) Bring children aged 0-6 
years old to health facility in accordance with health procedure of $\mathrm{PKH}$ for children; and (3) For pregnant mothers, they must check their health up and their fetus to health facility in accordance with health procedure of PKH for pregnant mothers.

Table 8 - Informants' Assessments on Punctuality PKH Program

\begin{tabular}{|c|l|c|c|}
\hline No & \multicolumn{1}{|c|}{ Description } & Total & $\%$ \\
\hline 1 & It is punctual & 12 & 80 \\
\hline 2 & It is not punctual yet & 3 & 20 \\
\hline \multicolumn{2}{|c|}{ Grand Total } & 15 & $100 \%$ \\
\hline
\end{tabular}

Source: Processed Survey Data, 2016.

Efficiency and Effectivity of PKH Program. Based on the result of survey, it can be known that $53,3 \%$ informants believe that PKH Program is highly effective to help improving the community's welfare and $46,7 \%$ informants assume that PKH Program is efficient.

Table 9 - Informants' Assessment on Efficiency and Effectivity of PKH Program

\begin{tabular}{|c|l|c|c|}
\hline No & Description & Amount & $\%$ \\
\hline 1 & It is efficient & 8 & 53,3 \\
\hline 2 & It is effective & 7 & 46,7 \\
\hline Total & 15 & $100 \%$ \\
\hline
\end{tabular}

Source: Processed Survey Data, 2016.

The components that become the main focus are health and education aspects. The main goal of PKH in Health is to enhance health status of mothers and children in Indonesia, especially for a very poor community, through incentives giving to have a preventive health visit (it is prevention and not a cure). All PKH participants are the recipients of free health service provided by Poor Health Assurance (Askeskin) Program and other programs that are for poor people. Thus, PKH card can be used as identity card to get the service. The education component in $\mathrm{PKH}$ is developed to increase participation rate of nine-year compulsory education and as an effort to reduce child workers in a very poor family. The children recipients of $\mathrm{PKH}$ in Education which aged 7-18 years old and do not accomplish nine-year compulsory education yet must register themselves first in formal school or non formal school and they must attend classes at least $85 \%$ meetings.

The reality in the field reveals that there are 25.878 Targeted Households (RTS) will be sent to join Household-targeted Social Assistance (PKH). The total is the validation result conducted by team. Previously, the total of Targeted Household (RTS) achieves 30.257 families, but after validation, it reduces to 4.379 families. The validation process was conducted by central government because the data was obtained from Social Protection Program Survey (PPLS) 2011. There are 4.379 families which are considered not fulfilling the requirements to join the program. The result is then followed up by team of Klaten Regency.

Reliability of PKH Program. Based on the survey result, it reveals that $86,6 \%$ informants assume that the realization of PKH Program is reliable and $13,4 \%$ informants assess that $\mathrm{PKH}$ program realization is not reliable yet.

Table 10 - Informants' Assessment on Reliability of PKH Program

\begin{tabular}{|c|l|c|c|}
\hline No & \multicolumn{1}{|c|}{ Description } & Amount & $\%$ \\
\hline 1 & It is reliable & 13 & 86,6 \\
\hline 2 & It is not reliable & 2 & 13,4 \\
\hline \multicolumn{2}{|c|}{ Total } & 15 & $100 \%$ \\
\hline
\end{tabular}

Source: Processed Survey Data, 2016.

$\mathrm{PKH}$ is an inter-ministerial and institutional program because its main actors are from National Development Planning Board, Department of Social, Department of Health, Department of National Education, Department of Religion, Department of Informatics and 
Communication, and Central Bureau of Statistics. PKH is more concerned on the effort to develop social protection system for community. This program is prioritized more on giving cash assistance for poor people (Very Poor Household (Rumah Tangga Sangat Miskin / RSTM) that fulfill requirements regarding to the effort to enhance human resources through education and health. The amount of cash assistance for PKH Participants is various depending on the numbers of family members counted in assistance targets, both components of health and education. The amount of this assistance can be changed depending on the condition of participant family in accordance with prevailing requirements.

The factors that influence the efforts of Klaten Regency government in enhancing community's welfare through people-based economy program realization:

Communication Factor. The interview result expresses that the problem of communication is shown by the problem in data collection. The problem in field makes communication not run well so that the effort to prevent is slow as well. The problems that arise are empty house, uncompleted address, unknown address, and the household moves. These should be handled soon and the data should be fixed immediately minimum once a year through data checking. Other problems that are also faced are in terms of distributing Rice for Poor (Raskin), BSM, PKH in the realization of people-based economy program, in the update of data if Targeted Household (RTS) is empty, address is not completed, address is not known, the household is moved, the delivery is rejected, and the household whose all family members have passed away, so that it needs long time in its realization.

Resources Factor. The whole data result either documentation or interview shows that there are two factors of human resources aspect which are (1) supporting factor is shown in form of the owned same competence so that all TKSK is considered being able to run a duty; guidance book and some coordination are conducted to help TKSK in running their responsibilities. (2) On the other hand, there is inhibiting factor which means inability of TKSK in giving punctual and sensitive roles on misappropriation of program realization if it is found; the inability to participate in supervising the realization, and be able to balance and to communicate the problems and the findings so that it can attract attention of project leader and implementers in order to make correction and evaluation; and the inability of TKSK in giving clear guidance for community.

Disposition or Attitude Factor. The whole obtained data on aspect of disposition or attitude reveals that there are inhibiting factors indicated by: (1) the short and the hurried socialization process so that many people do not understand about P4S Program (Rice for Poor (Raskin), Poor Students Assistance (BSM), and Household-targeted Social Assistance (PKH) (2) the attitude of most people who consider that the assistance is their right and it can be used anytime. These give obstacles for program goal achievement which is using the assistance as the business capital. (3) Tendency of village officials who feel ignorant to take responsibilities to verify data of Social Protection Card (KPS) holders.

Bureaucracy Structure. Based on the whole data above, it shows that there are inhibiting factors in bureaucracy structure which are marked by: (1) its implementation is less coordinative because its data collection does not involve local village head or local government, so that its distribution is considered not effective because its data is not in line with the fact in field. It can be seen tangibly from the community which actually do not deserve, but they get the card (2) the establishment of complaint center without giving clear information and authority will not help solving the problems.

\section{CONCLUSION}

The result of data findings mark that the efforts of Klaten Regency government in enhancing community welfare through people-based economy are conducted by planning Social Protection Extension and Acceleration Program (P4S) as compensation of increasing fuel price. The recipient targets of P4S Objectives are poor households. Every poor household will get Social Protection Card (KPS) without any charge. This card is the marker that they deserve to obtain benefits of social protection program which is in line with prevailing provisions of each program. The program is the social security net consisting of 
program extension of rice subsidy for low-income society (Subsidy of Rice for Poor/Raskin), Household-targeted Social Assistance/Program Keluarga Harapan (PKH), and Poor Students Assistance/Program Bantuan Siswa Miskin (BSM). The factors that influence the efforts of Klaten Regency government in enhancing community welfare through peoplebased economy are as follows: communication, resources, disposition or attitude, and bureaucracy structure.

\section{REFERENCES}

1. Albornoz, M. A., Becker, M., Cahyat, A., Cronkleton, P., Jong, W.d., Evans, K., Wollenberg, E., 2007, Menuju Kesejahteraan dalam Masyarakat Hutan: Buku Panduan untuk Pemerintah Daerah. Bogor: Cifor.

2. Badan Pusat Statistik (BPS). 2015. Indikator Sosial Ekonomi Indonesia. Badan Pusat Statistik Indonesia. Jakarta.

3. Locatelli, B., Kanninen, M., Brockhaus, M., Colfer, C. J., Murdiyarso, D., \& Santosa, H. 2009. Menghadapi Masa Depan Yang Tak Pasti: Bagaimana Hutan dan Manusia Beradaptasi terhdap Perubahan Iklim. Bogor: Cifor.

4. Miles, M.B dan Huberman. 1998. Analisis Data Kualitatif. Terjemahan T.R. Rohidi. Jakarta: UI.

5. Peraturan Menteri No. 42 tahun 2010 tentang Struktur Kelembagaan dan Mekanisme Kerja Tim Koordinasi Penanggulangan Program

6. Peraturan Presiden Republik Indonesia Nomor 15 Tahun 2010 Tentang Percepatan Penanggulangan Kemiskinan

7. Sutopo, H.B. 2002. Metodologi Penelitian Kualitatif: Dasar teori dan Terapannya dalam Penelitian. Surakarta: Universitas Sebelas Maret.

8. Todaro, Michael P dan Stephen C. Smith. 2008. Pembangunan Ekonomi. Edisi kesembilan. Jakarta: Erlangga

9. World Bank. 2008. Making the New Indonesia Work for the Poor. The World Bank. 